\title{
TERMELÉSTERVEZÉSI MÓDSZEREK HATÉKONYSÁGÁNAK VIZSGÁLATA RUGALMAS GYÁRTÓRENDSZER SZIMULÁCIÓS MODELLJÉVEL
}

\author{
Tóth Norbert \\ tudományos munkatárs, Bay Zoltán Nonprofit Kft. \\ 3519 Miskolc, e-mail: norbert.toth@bayzoltan.hu
}

\section{Kulcsár Gyula}

egyetemi docens, Miskolci Egyetem, Informatikai Intézet, Alkalmazott Informatikai Intézeti Tanszék

3515 Miskolc, Miskolc-Egyetemváros, e-mail: iitkgy@uni-miskolc.hu

\begin{abstract}
Absztrakt
A cikk bemutatja egy rugalmas gyártórendszer szimulációs modelljét, amelyben a humán eröforrás kulcsszerepet játszik. A termeléstervezési feladat hatékony megoldására egy speciális keresési módszert javaslunk, amely figyelembe veszi a müszakokban dolgozó emberek valós gyártási képességeit a müszakokra vonatkozó munkák kiosztása során. A feladatot egy másik megközelitéssel is megoldjuk, melynek lényege, hogy a termeléstervezési feladatot visszavezetjük permutációs optimalizálási problémára és a Plant Simulation szoftver genetikus algoritmusával oldjuk meg. A két módszert összehasonlítjuk a vizsgált rugalmas gyártórendszer szimulációs modelljének segitségével és bemutatjuk a futási eredményeket.
\end{abstract}

Kulcsszavak: digitális modell, szimuláció, termeléstervezés, genetikus algoritmus

\begin{abstract}
The paper presents a simulation model of a flexible manufacturing system in which human resources play key roles. To effectively solve production planning problems, we propose a special search method that takes into account the real manufacturing capabilities of the people working in shifts, when the jobs are assigned to the shifts. We solve the problem with another approach. The essence of this method is to transform the production planning problem to the permutation optimization problem and solve it with the genetic algorithm of Plant Simulation. We compare these two methods using the simulation model of the studied flexible manufacturing system and present the running results.
\end{abstract}

Keywords: digital model, simulation, production planning, genetic algorithm

\section{Bevezetés}

A termelés globalizációja, a vevői igények minél magasabb szintủ kielégítése egyre nagyobb kihívások elé állítja a termelő vállalatokat a termelési kapacitásuk minél hatékonyabb kihasználása érdekében. Ezt az Ipar 4.0 paradigmához kapcsolódó digitalizációs és új infokommunikációs megoldások nagymértékben támogatják [1]. Az új technológiák alkalmazása a termelörendszerek struktúrájának átalakítását igényli, a munkaállomások nemlineáris - mátrix - elrendezésével manuális, rugalmas gyártó-szerelörendszerek (MFAS) [2] jönnek létre, amelyek magas fokú rugalmasságával biztosítják a vevői igényeknek megfelelö termékek gyártását és összeszerelését (assembly-to-order (ATO) [3]). 
A gyártási-szerelési múveleteket sok esetben dolgozók hajtják végre, akik a termelési folyamat szerves részét képezik. A terméktípusokon a gyártási-szerelési művelet elvégzése mellett a munkadarabok munkaállomások közötti mozgatásával biztosítják az egydarabos anyagáramlás megvalósulását (onepiece flow). A dolgozók gyártási képességei, mentális és fizikai tulajdonságai kulcsfontosságú szerepet játszanak a termelési folyamat hatékony müködésében [4], így a termeléstervezés és a termelésütemezés során meghatározó paraméterekként jelentkeznek.

A diszkrét gyártási feladatokhoz kapcsolódó klasszikus termelésütemezési problémák - egygépes (single machine), párhuzamos gépes (parallel machines) és többoperációs (shop) feladatok - változatos eseteit foglalja össze az [5] könyv. Az egyutas (flow shop) és többutas (job shop) termelésütemezési feladatok megoldási módszerei csak bizonyos speciális esetekben adnak optimális megoldást, mivel ezek a problémák az NP-hard osztályba sorolhatók [6]. A rugalmas gyártórendszerek ütemezési problémái szigorúan erőforrás-korlátos flow shop [7], [8], [9] és job shop [10], [11], [12], [13] típusú feladatokhoz kapcsolódnak leginkább, ahol az erőforrások magukba foglalják a termelő berendezéseket, munkaállomásokat, logisztikai eszközöket, műveletközi tárolókat, anyagmozgató berendezéseket és akár a dolgozókat (emberi erőforrásokat) is. Emiatt a termeléstervezési- és ütemezési feladatok megoldása során további müködési jellemzők és paraméterek figyelembevétele szükséges. Ezek tovább növelik a modellek komplexitását, mivel számos, a termelési folyamatot befolyásoló környezeti hatást integrálnak. Ezek a környezeti hatások a valós termelési rendszerek és folyamatok egyre részletesebb, egyre alacsonyabb szintü leképzése miatt kerülnek a vizsgálatok középpontjába. A valós rendszerek és folyamatok leképzését és vizsgálatát a szimulációs modellek nagymértékben támogatják [14], amelyek további előnye, hogy a digitális modelleken végzett fejlesztések, kísérletek a valós müködő rendszerben való bevezetés előtt kipróbálhatók, tesztelhetők a valós folyamatba való beavatkozás nélkül. A hatékony termeléstervezési és ütemezési algoritmusok teszteléséhez a valós rendszerek digitális modelljei segítségünkre lehetnek.

\section{Szimulációs modellel integrált termeléstervezés}

\subsection{A vizsgált feladat és a kidolgozott megoldási koncepció}

Korábbi cikkünkben [17] bemutatásra került egy olyan rugalmas gyártórendszer, amelyben a humán erőforrás gyártási képessége kulcsfontosságú szerepet játszott a maximális produktivitás elérésében. Megállapítottuk, hogy az emberi tényező jelentősége kiemelkedő fontossággal bír a müszakonkénti termelési tervek végrehajtása során. Elkészítettünk és bemutattunk egy diszkrét esemény-vezérelt szimulációs modellt, melynek lényegét az 1 . ábra vázolja. A szimulációs modellbe leképzésre kerültek:

- a vizsgált időszak müszakjai;

- a szünetek;

- a terméktípusok;

- a terméktípusokon végrehajtandó operációk;

- az operációk müveleti normaideje;

- a munkahelyek és a szerelóállomások, ahol az operációk elvégezhetők;

- a dolgozók;

- a dolgozók müszakbeosztása;

- a dolgozók gyártási képességei, amelyek az operációk műveleti normaidejét befolyásolják;

- az útvonalak, amelyek a dolgozók egydarabos anyagmozgatását biztosítják az egyes munkaállomások között, figyelembe véve az összes gyártható terméktípus lehetséges operációinak sorrendjét reprezentáló anyagáramlási relációkat. 


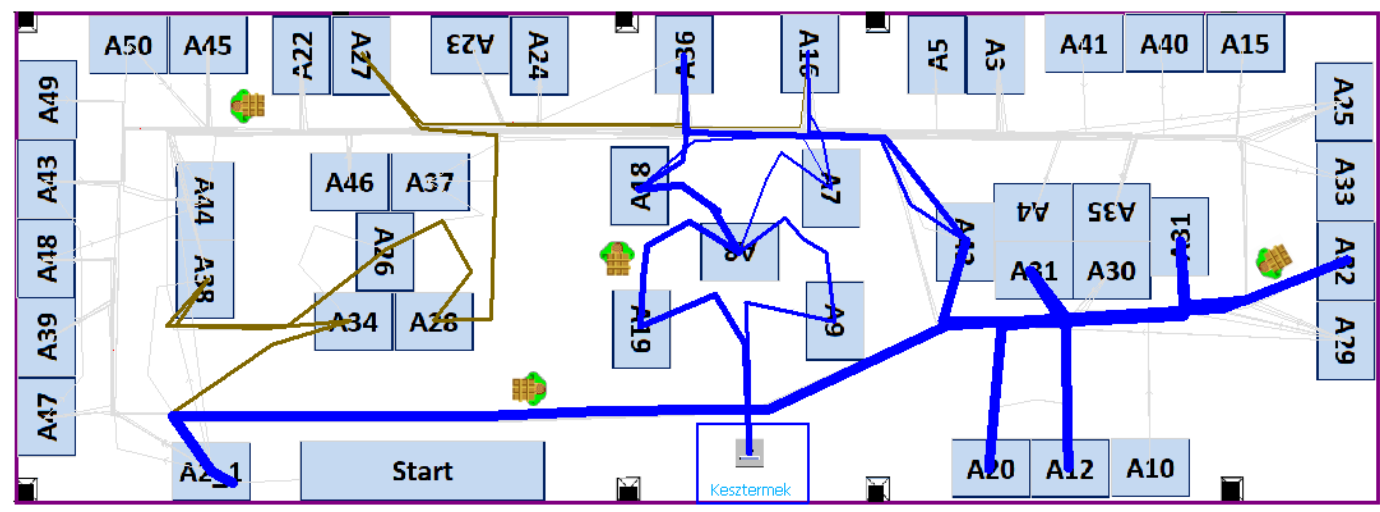

1. ábra. Szimulációs modell.

A gyártórendszer digitális modellje a Plant Simulation szimulációs szoftverben készült. Az objektumorientált fejlesztőeszköz rendkívül nagy szabadságot ad a felhasználó számára a valós rendszerben zajló folyamatok minél pontosabb leképzéséhez, amelyet az alkalmazás SimTalk programozási nyelve nagymértékben támogat. Nem csak algoritmusok, eljárások, függvények leírására alkalmas, hanem lehetőséget biztosít önálló modulok készítésével saját funkciók létrehozására is. Az alábbi folyamatábra (2. ábra) mutatja a saját fejlesztésủ termeléstervezö (PPO) modul müködését.

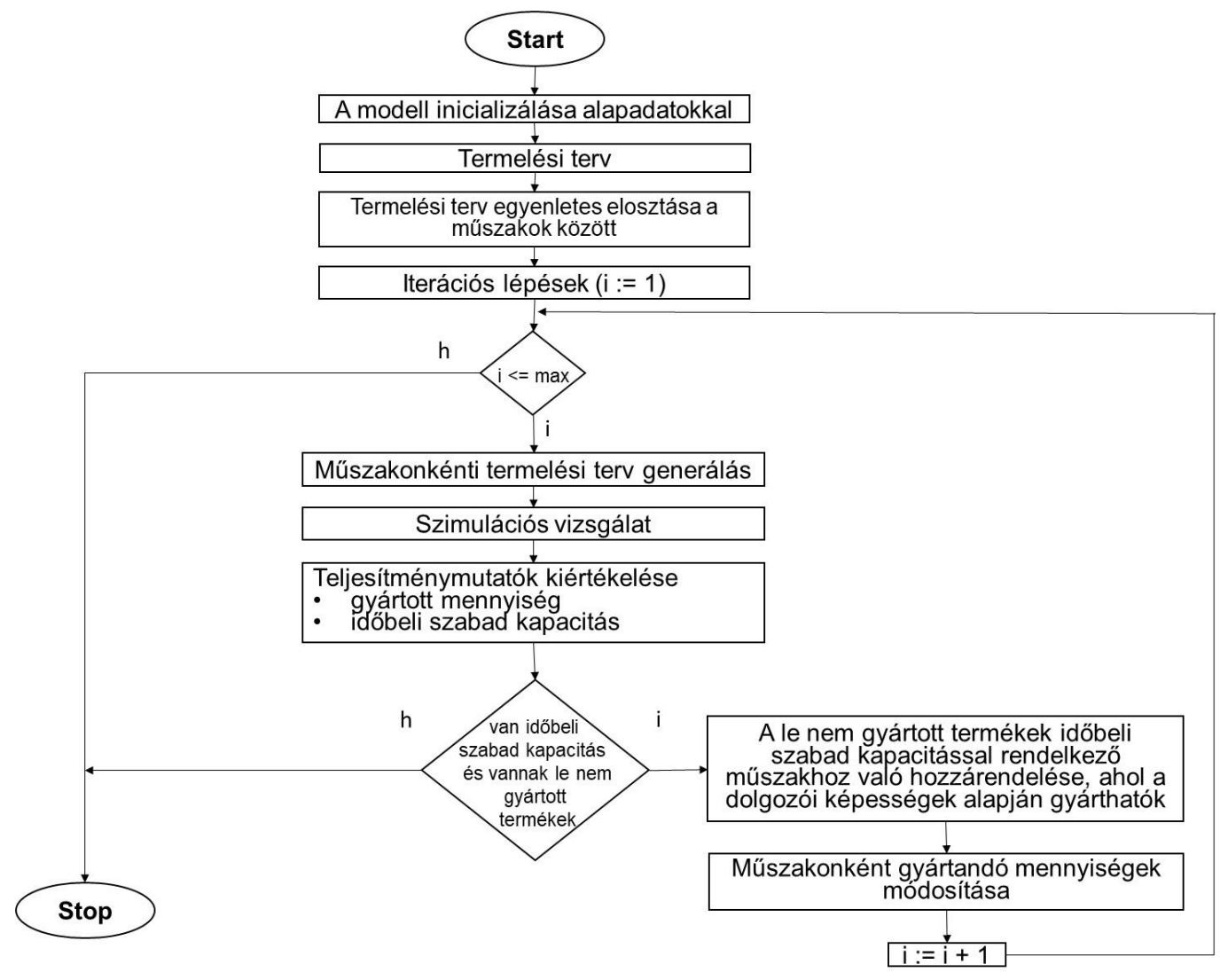

2. ábra. A PPO modul iteratív kereső algoritmusának folyamatábrája. 
Az általunk kidolgozott PPO modul a vizsgált valós rendszer müszakonkénti termeléstervezését és optimalizálását végzi a dolgozók valós gyártási képességeinek figyelembevételével. A kidolgozott heurisztikus iteratív kereső algoritmus alkalmas az adott időhorizontra vonatkozó termelési tervből kiindulva müszakonkénti termelési résztervek generálására a dolgozói képességek figyelembevételével úgy, hogy a termelési rendszer hatékonysága javul a kitüzött célfüggvények (a gyártott darabszám és a rendszer időbeli szabad kapacitása) szempontjából.

\subsection{A PPO modul müködési stratégiái és eredményei}

A PPO modul termelési tervet módosító funkciójának teszteléséhez kidolgoztunk és implementáltunk egy másik módszert, amely a vizsgált időszakra ugyanazzal a kereső algoritmus-vázzal müködik, de a megoldást módosító mủvelet eltér az eredeti módosító mủvelettől.

A PPO célirányosan kiválasztott két szempontot vesz figyelembe az el nem végzett munkák valamely másik müszakhoz való hozzárendelése során: Egy adott müszakban lévő le nem gyártott munkadarab akkor és csakis akkor rendelhető másik müszakhoz, ha az alábbi követelmények teljesülnek (A eset):

- a befogadó müszak tartalékidővel rendelkezik, azaz van elegendő időbeli szabad kapacitása;

- a befogadó müszakhoz rendelt dolgozók között van olyan, aki a valós gyártási képességével el tudja végezni az adott munkát.

A két feltétel együttes teljesülése esetén a munka a jelölt befogadó müszakhoz rendelhető. A következő iterációs lépés szimulációs vizsgálatában a módosított termelési terv szerepel. Amennyiben nincs alkalmas müszak a munka nem helyezhető át.

Az algoritmus teszteléséhez az el nem végzett munkák és a befogadó müszakok összerendelésének feltételeit a következőre változtattuk meg (B eset):

- az adott müszakban el nem végzett munkák bármely másik véletlenszerüen választott müszakhoz hozzárendelhetők, függetlenül a választott müszak szabad időkapacitásától és a dolgozók valós gyártási képességeitől.

A két ( $A$ és $B$ ) eset összehasonlításához a szimulációs vizsgálatokat és a PPO modul algoritmusának müködését az alábbi modell-beállításokkal végeztük (1. táblázat).

1. táblázat. Szimulációs modell beállitásai a PPO teszthez

\begin{tabular}{|c|c|c|}
\hline Operációk müveleti ideje & \multicolumn{2}{|c|}{ a dolgozók átlagos képességétől függő } \\
\hline Alternatív munkahely csoportok & \multicolumn{2}{|c|}{$\begin{array}{l}\text { Group_1: } A_{36}, A_{16} \\
\text { Group_2: } A_{9}, A_{19} \\
\text { Group_3: } A_{18}, A_{7}\end{array}$} \\
\hline Munkahelyválasztás stratégiája & \multicolumn{2}{|c|}{ ahol a munkahely előtt várakozó dolgozók száma kevesebb } \\
\hline Munkaválasztás stratégiája & \multicolumn{2}{|c|}{$\begin{array}{l}\text { a dolgozó által gyártható első munkadarabot választja a müszakban } \\
\text { még le nem gyártott munkadarabok várakozó sorából }\end{array}$} \\
\hline Müszakok száma & \multicolumn{2}{|l|}{10} \\
\hline $\begin{array}{l}\text { Dolgozók }(H) \text { és müszakok }(T) \\
\text { összerendelése }\end{array}$ & $\begin{array}{l}\mathrm{D}=\mathrm{T}_{1}: \mathrm{H}_{10}, \mathrm{H}_{11}, \mathrm{H}_{12}, \mathrm{H}_{16}, \mathrm{H}_{20} \\
\mathrm{~A}=\mathrm{T}_{2}: \mathrm{H}_{1}, \mathrm{H}_{2}, \mathrm{H}_{3}, \mathrm{H}_{7}, \mathrm{H}_{13} \\
\mathrm{~B}=\mathrm{T}_{3}: \mathrm{H}_{4}, \mathrm{H}_{5}, \mathrm{H}_{6}, \mathrm{H}_{14}, \mathrm{H}_{18} \\
B=\mathrm{T}_{4}: \mathrm{H}_{4}, \mathrm{H}_{5}, \mathrm{H}_{6}, \mathrm{H}_{14}, \mathrm{H}_{18} \\
C=\mathrm{T}_{5}: \mathrm{H}_{8}, \mathrm{H}_{9}, \mathrm{H}_{15}, \mathrm{H}_{19}\end{array}$ & $\begin{array}{l}\mathrm{B}=\mathrm{T}_{6}: \mathrm{H}_{4}, \mathrm{H}_{5}, \mathrm{H}_{6}, \mathrm{H}_{14}, \mathrm{H}_{18} \\
\mathrm{~A}=\mathrm{T}_{7}: \mathrm{H}_{1}, \mathrm{H}_{2}, \mathrm{H}_{3}, \mathrm{H}_{7}, \mathrm{H}_{13} \\
B=\mathrm{T}_{8}: \mathrm{H}_{4}, \mathrm{H}_{5}, \mathrm{H}_{6}, \mathrm{H}_{14}, \mathrm{H}_{18} \\
\mathrm{~A}=\mathrm{T}_{9}: \mathrm{T}_{2}: \mathrm{H}_{1}, \mathrm{H}_{2}, \mathrm{H}_{3}, \mathrm{H}_{7}, \mathrm{H}_{13} \\
C=\mathrm{T}_{10}: \mathrm{H}_{8}, \mathrm{H}_{9}, \mathrm{H}_{15}, \mathrm{H}_{19}\end{array}$ \\
\hline $\begin{array}{l}\text { Termelési terv } \\
\text { (Terméktípus/mennyiség) }\end{array}$ & \multicolumn{2}{|c|}{ _1257 / 280;_15A7 / 538;_0601 / 649;_1607 / 412} \\
\hline $\begin{array}{l}\text { Termelési tervek szétosztása a } \\
\text { müszakok között inicializáláskor }\end{array}$ & \multicolumn{2}{|l|}{ egyenletes elosztás } \\
\hline
\end{tabular}


A tesztet mindkét esetben azonos modellbeállítások mellett végeztük. A vizsgált időszak 10 müszakot foglalt magába. Az 1. táblázatban látható , $A$, , $B$, , $C$ ” és „, $D$ ” múszaktípusok egy adott kombinációja alkotta a müszakrendet. Minden müszaktípushoz a dolgozók egy dedikált csoportja tartozott. A 10 müszak alatt 4 különböző terméktípus eltérő számú munkadarabjának gyártását kellett elvégezni. A PPO modul kiinduló megoldását (a müszakonkénti termelési tervét) mindkét esetben ugyanazzal az eljárással (egyenletes elosztással) végeztük annak érdekében, hogy az induló állapotok megegyezzenek. A szimulációs vizsgálatot a PPO algoritmus nélkül is elvégeztük, így az induló megoldás eredményei is ismertté váltak. A háromféle kísérlet eredményeit a 2. táblázat foglalja össze.

2. táblázat. Szimulációs eredmények

\begin{tabular}{|l|c|c|c|}
\hline \multirow{2}{*}{ Mutatók } & \multirow{2}{*}{ PPO nélkül } & \multicolumn{2}{|c|}{ PPO-val } \\
\cline { 3 - 4 } & & A-eset & B-eset \\
\hline tervezett mennyiség $(\mathrm{db})$ & 1879 & 1879 & 1879 \\
\hline gyártott mennyiség (db) & 1858 & 1879 & 1879 \\
\hline időbeli szabad kapacitás (min) & 193.06 & 127.25 & 147.06 \\
\hline iterációs lépések (db) & - & 5 & 10 \\
\hline
\end{tabular}

A PPO algoritmus nélkül az egyenletes elosztású termelési terv nem valósult meg hiánytalanul, mert a kiosztott munkák egy része nem teljesült az adott müszakokban. A PPO alkalmazásával mindkét esetben legyártásra került az elöírt teljes mennyiség a munkák alkalmas műszakhoz való hozzárendelése révén. A PPO algoritmus használatával mindkét esetben a tervezett darabszámok legyártásra kerültek. Megfigyelhető viszont az iterációs lépések közötti különbség (3. ábra).

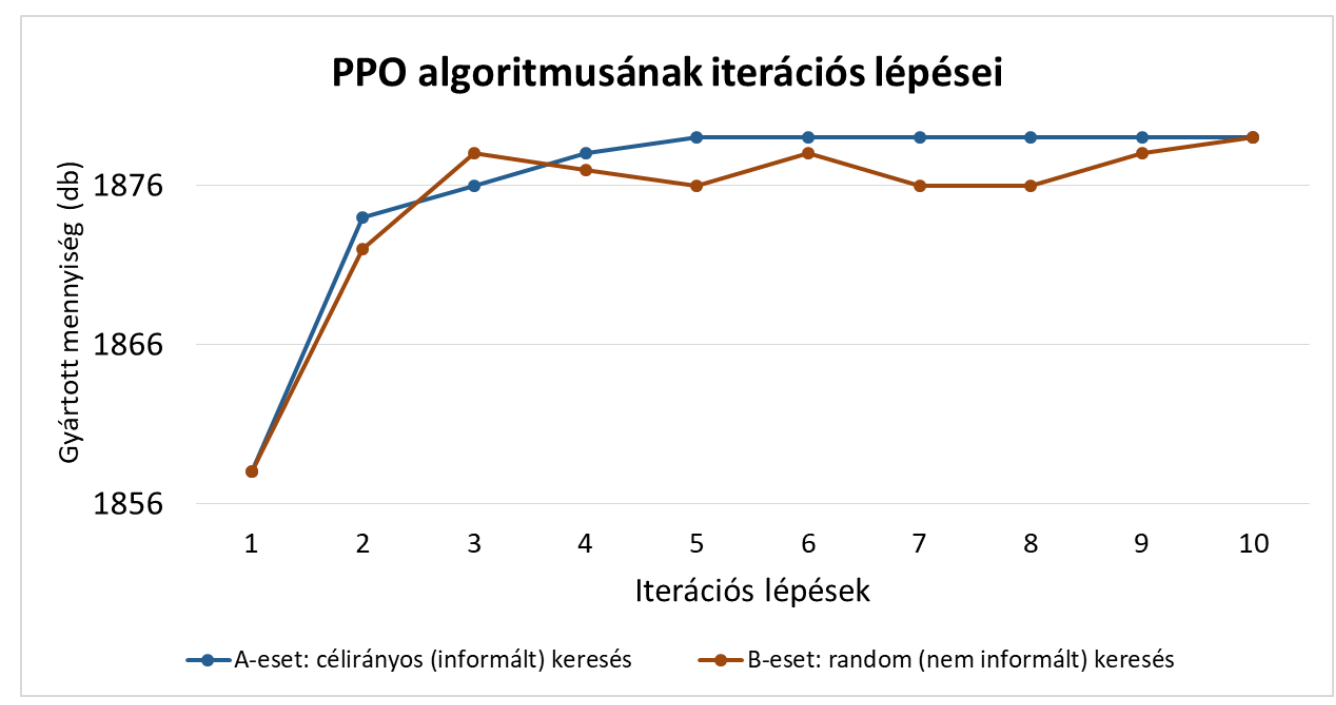

3. ábra. Iterációs lépések száma a PPO különbözö stratégiái mellett.

Az A-esetben a PPO algoritmusa figyelembe vesz olyan szempontokat is, amelyek a le nem gyártott munkadarabok alkalmas müszakhoz való hozzárendelését segítik, így a kereső algoritmus célirányosan tudja módosítani a műszakonkénti termelési terveket (informált keresés). Ezzel szemben a Besetben a le nem gyártott munkadarabokat ,random” módon rendeli egy-egy müszakhoz (nem informált „vak” kereséssel). Emiatt az iterációk száma - már ebben az illusztratív példában is - duplájára nőtt és így a futási idő is a duplájára nőtt. 
Az elvégzett vizsgálatok igazolták, hogy a müszakokban dolgozók valós gyártási képességeinek figyelembevétele a termeléstervezésben és a termelési tervek optimalizálásában is kiemelt fontossággal bír.

\section{A PPO algoritmus hatékonyságának vizsgálata}

A Plant Simulation (PS) rendelkezik egy olyan beépített optimalizáló objektummal, amellyel lehetőség nyílik számos optimalizálási feladat megoldására. Ez az objektum egy általános genetikus algoritmust (GA) alkalmaz az optimalizálási feladatok megoldása során [15], [16]. A PPO algoritmusunk hatékonyságát a Plant Simulation GA módszerének (PSGA) hatékonyságával hasonlítottuk össze. Ennek érdekében elkészítettünk egy tesztkörnyezetet, amelynek beállításait a 3. táblázat foglalja össze.

3. táblázat. PPO tesztadatok PSGA teszthez

\begin{tabular}{|c|c|}
\hline Operációk müveleti ideje & a dolgozók átlagos képességétől függő \\
\hline Alternatív munkahely csoportok & $\begin{array}{l}\text { Group_1: } A_{36}, A_{16} \\
\text { Group_2: } A_{9}, A_{19} \\
\text { Group_3: } A_{18}, A_{7}\end{array}$ \\
\hline Munkahelyválasztás stratégiája & $\begin{array}{l}\text { ahol a munkahely előtt várakozó dolgozók száma keve- } \\
\text { sebb }\end{array}$ \\
\hline Munkaválasztás stratégiája & $\begin{array}{l}\text { a dolgozó által gyártható első munkadarabot választja a } \\
\text { müszakban még le nem gyártott munkadarabok várakozó } \\
\text { sorából }\end{array}$ \\
\hline Müszakok száma & 5 \\
\hline $\begin{array}{l}\text { Dolgozók }(H) \text { és müszakok össze- } \\
\text { rendelése }(T)\end{array}$ & $\begin{array}{l}\mathrm{C}=\mathrm{T}_{1}: \mathrm{H}_{8}, \mathrm{H}_{9}, \mathrm{H}_{15}, \mathrm{H}_{19} \\
\mathrm{~A}=\mathrm{T}_{2}: \mathrm{H}_{1}, \mathrm{H}_{2}, \mathrm{H}_{3}, \mathrm{H}_{7}, \mathrm{H}_{13} \\
\mathrm{~B}=\mathrm{T}_{3}: \mathrm{H}_{4}, \mathrm{H}_{5}, \mathrm{H}_{6}, \mathrm{H}_{14}, \mathrm{H}_{18} \\
\mathrm{~A}=\mathrm{T}_{4}: \mathrm{H}_{1}, \mathrm{H}_{2}, \mathrm{H}_{3}, \mathrm{H}_{7}, \mathrm{H}_{13} \\
D=\mathrm{T}_{5}: \mathrm{H}_{10}, \mathrm{H}_{11}, \mathrm{H}_{12}, \mathrm{H}_{16}, \mathrm{H}_{20}\end{array}$ \\
\hline $\begin{array}{l}\text { Termelési terv } \\
\text { (Terméktípus / mennyiség) }\end{array}$ & 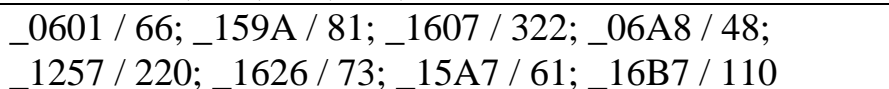 \\
\hline $\begin{array}{l}\text { Termelési tervek szétosztása a } \\
\text { müszakok között inicializáláskor }\end{array}$ & egyenletes elosztás \\
\hline
\end{tabular}

\subsection{Termelési tervek optimalizálása PPO módszerrel}

A fenti beállításokkal szimulációs vizsgálat készült a PPO müködéséről, amelynek eredményét a 4. táblázat mutatja. A termelési terv egyenletes elosztása miatt (inicializálás során) vannak le nem gyártott munkadarabok és van a rendszernek szabad időkapacitása is $(\exp =1)$. A következő vizsgálat előtt a PPO új megoldást (müszakonkénti termelési tervet) generált a le nem gyártott munkadarabok alkalmas müszakba való áthelyezésével.

Az új termelési tervvel ismét lefutott a szimulációs vizsgálat (exp $=2)$. Ez az iteratív folyamat a leállási feltételek teljesüléséig folytatódott. Az egyes iterációs lépések szimulációs vizsgálatának eredményét a 4. táblázat foglalja össze, amely igazán jól mutatja, hogy a PPO módszer már kis számú iterációs lépés mellett is képes jelentős javulást elérni a vizsgált termelési rendszer produktivitásában a 
kvázi-optimális műszakonkénti termelési terv készítésével. A munkák alkalmas müszakba való átrendezésével minden munkadarab legyártásra került.

4. táblázat. PPO algoritmus futási eredmények

\begin{tabular}{|c|c|c|c|c|c|c|c|c|}
\hline \multirow{2}{*}{$\exp$} & \multirow{2}{*}{$\begin{array}{c}\text { Gyártott } \\
\text { mennyiség }\end{array}$} & \multirow{2}{*}{$\begin{array}{c}\text { Le nem gyár- } \\
\text { tott mennyi- }\end{array}$} & \multicolumn{5}{|c|}{ A rendszer szabad időkapacitása } \\
\cline { 5 - 10 } & $(\mathrm{db})$ & \multirow{2}{*}{$\begin{array}{c}\text { Összesen } \\
(\mathrm{db})\end{array}$} & $(\mathrm{min})$ & $\mathrm{T}_{1}$ & $\mathrm{~T}_{2}$ & $\mathrm{~T}_{3}$ & $\mathrm{~T}_{4}$ & $\mathrm{~T}_{5}$ \\
\hline 1 & 957 & 24 & 115.41 & 0.00 & 21.37 & 45.11 & 26.12 & 22.82 \\
\hline 2 & 973 & 8 & 75.40 & 5.24 & 21.37 & 0.00 & 23.09 & 25.70 \\
\hline 3 & 976 & 5 & 52.56 & 5.24 & 21.37 & 0.00 & 25.95 & 0.00 \\
\hline 4 & 980 & 1 & 40.76 & 5.24 & 7.25 & 1.32 & 26.94 & 0.00 \\
\hline 5 & 981 & 0 & 42.43 & 5.24 & 7.25 & 1.32 & 21.17 & 7.45 \\
\hline
\end{tabular}

\subsection{Termelési tervek optimalizálása PSGA módszerrel}

A vizsgált termeléstervezési feladatot PSGA módszerrel is szerettük volna megoldani a saját PPO módszerünkkel való összehasonlítás érdekében.

A PS genetikus kereső algoritmusának meg kell adni az optimalizálandó paramétereket, valamint a célfüggvényt vagy a célfüggvényeket és azok súlyozó értékeit. Az optimalizálandó paraméterek a legtöbb esetben a vizsgált rendszer változtatható paraméterei közül kerül ki. Ezek olyan paraméterek, amelyek értékeinek változása hatással van a rendszer müködésére. Ekkor a PSGA objektuma szimulációkat futtat az optimalizálandó paraméterek különböző értékeinek beállításával, amely mellett számítja a (fitness) célfüggvény értékét. A paraméterek értékeinek következő kombinációját a már rendelkezésre álló futási eredmények (egyedek) fitness függvényértéke alapján genetikus algoritmussal határozza meg.

Esetünkben viszont nem a rendszerparaméterek különböző értékeinek kombinációjából kiindulva kell megtalálnunk a legjobb beállítást (megoldást), hanem a termelési tervben szereplő gyártandó mennyiségeket (a munkákat) kell úgy szétosztani a müszakok között, hogy a vizsgált célfüggvényértéket maximalizáljuk. Ehhez a feladathoz a müszakonkénti termelési tervet genetikus algoritmussal módosítjuk és az aktuális kombináció mellet készül el a szimulációs vizsgálat és értékelődnek ki a célfüggvények. A termelési terv ilyen jellegü optimalizálására a PSGA objektum közvetlenül nem alkalmas.

A feladat megoldása érdekében egy új modell-transzformációs technikát dolgoztunk ki. Ennek lényege az, hogy a teljes termelési tervet egy alkalmasan megválasztott reprezentációs sémába transzformáltuk. Ez leképezhető egy listára, melynek segítségével adjuk át a PSGA számára. és a szimuláció előtt a generált (módosított) listát visszatranszformáljuk termelési tervvé. Így a termelési tervet leképeztük adott számú elem permutációjára. A termelési terv optimalizálásának feladatát (termeléstervezést) visszavezettük egy általános kombinatorikai feladattá, amelyben a célfüggvényérték egy vektor elemeinek sorrendjétől függ. Így a PSGA permutációra alapozott algoritmusa használhatóvá vált.

A megoldás (termelési terv) reprezentációs sémáját úgy terveztük meg, hogy a döntési változókat tartalmazó lista (egyed) hossza nem csak a tervezett munkák számával egyezik meg, hanem a tervezett munkák és a vizsgált időszakhoz tartozó müszakok számának szorzatával. A lista egy eleme vagy egy adott munka sorszáma lehet, vagy pedig nulla. A nulla elemek „pozíció-kitöltő” szerepet játszanak. Ezek segítségével biztosítjuk, hogy a vektor hossza mindig konstans legyen, ugyanakkor az összes 
lehetséges hozzárendelési lehetőség ábrázolható legyen. A lista elemei indexeltek és a lista minden eleméről megmondható, hogy melyik müszakhoz tartozik. Ekkor a PSGA által generált lista (permutáció) miden eleméről az indexe (sorszáma) alapján egyértelmüen megállapítható, hogy melyik műszakhoz tartozik.

A kidolgozott módszert egy egyszerü illusztratív feladaton keresztül mutatjuk be. Legyen egy termelési terv a következő: P1 terméktípusból 4 db gyártandó. A gyártandó munkák ekkor $J_{1}, J_{2}, J_{3}, J_{4}$. A munkák elvégzésére 3 müszak $\left(T_{1}, T_{2}, T_{3}\right)$ áll rendelkezésre. Ekkor a sémánk egy megoldást (egyedet) leíró kromoszómája $4 * 3=12$ db számú gént tartalmaz. A kromoszómában - az indexelt lista elemei - az 1-4 gének az 1. müszakot, az 5-8 gének a 2. müszakot, a 9-12 gének a 3. müszakot reprezentálják. Egy lehetséges megoldás (egyed) egy kromoszómával reprezentálható, amely a munkák és müszakok összerendelését írja le (5. táblázat).

5. táblázat. GA kromoszóma

\begin{tabular}{|c|c|c|c|c|c|c|c|c|c|c|c|c|}
\hline \multirow{4}{*}{$T_{1}$} & \multicolumn{5}{c|}{$T_{2}$} & \multicolumn{5}{c|}{$T_{3}$} \\
\cline { 2 - 13 } \\
\cline { 2 - 11 } & $J_{1}$ & $J_{2}$ & 0 & 0 & $J_{3}$ & 0 & 0 & 0 & $J_{4}$ & 0 & 0 & 0 \\
\cline { 2 - 6 }
\end{tabular}

Öt egyedet magába foglaló populáció illusztrációját mutatja a 6. táblázat.

6. táblázat. GA populáció

\begin{tabular}{l|c|c|c|c|c|c|c|c|c|c|c|c|} 
kromoszóma 1 & $J_{1}$ & $J_{2}$ & 0 & 0 & $J_{3}$ & 0 & 0 & 0 & $J_{4}$ & 0 & 0 & 0 \\
\cline { 2 - 13 } $\begin{array}{l}\text { kromoszóma 2 } \\
\text { kromoszóma 3 }\end{array}$ & 0 & $J_{3}$ & 0 & $J_{2}$ & 0 & 0 & 0 & 0 & $J_{1}$ & $\mathrm{~J}_{4}$ & 0 & 0 \\
\cline { 2 - 12 } $\begin{array}{l}\text { kromoszóma 4 } \\
\text { kromoszóma 5 }\end{array}$ & $J_{1}$ & $J_{3}$ & 0 & 0 & $J_{4}$ & 0 & 0 & 0 & 0 & 0 & 0 \\
\cline { 2 - 13 } & 0 & 0 & 0 & 0 & $J_{3}$ & 0 & $\mathrm{~J}_{4}$ & 0 & $J_{1}$ & $J_{2}$ & 0 & 0 \\
\cline { 2 - 12 } & 0 & 0 & 0 & $J_{3}$ & 0 & 0 & $\mathrm{~J}_{1}$ & 0 & 0 & 0 & $J_{2}$ \\
\cline { 2 - 9 }
\end{tabular}

A saját fejlesztésủ modell-transzformációs technika alkalmazásával felkészítettük a PSGA módszert a vizsgált termeléstervezési feladat megoldására. A PSGA müködési paramétereinek a beállítását a 7. táblázat adatai alapján végeztük el.

7. táblázat. Plant Simulation GA paraméterei

\begin{tabular}{|l|l|}
\hline Optimalizálandó paraméter & munkák müszakonkénti vektora \\
\hline Fitness függvény & $\begin{array}{l}\text { gyártott mennyiség: súly:0.7 } \\
\text { összes maradék idő: súly: 0.3 }\end{array}$ \\
\hline Optimalizálás iránya & Maximum \\
\hline Generációk száma & 3000 \\
\hline Populáció mérete & 10 \\
\hline $\begin{array}{l}\text { Genetikus múveletekre vo- } \\
\text { natkozó beállítások }\end{array}$ & $\begin{array}{r}\text { Keresztezés típusa: OX (order crossover), } \\
\text { kezdeti valószínüség: } 0.8 \\
\text { Genetikus operátor: Mutation, } \\
\text { kezdeti valószínűség: } 0.1\end{array}$ \\
\hline
\end{tabular}

A PSGA vizsgálatok tesztkörnyezete megegyezett a PPO beállításaival (3. táblázat) és a PSGA kezdeti termelési terve (az induló állapota) szintén a müszakonkénti egyenletes elosztásból származott. 
A PSGA objektum az optimalizálás első lépéseként adott állapotból kiindulva inicializálja a kezdeti populációt és minden egyes egyedre kiértékeli a fitness függvényt. Az aktuális populáció egyedeiből a beállítások alapján újabb populációt generál. A populáció minden egyes egyede (kromoszómája) egyegy lehetséges megoldást (müszakonkénti termelési tervet) jelent. A PSGA befejezi a müködését, ha a fitness érték már nem javítható vagy a generált populációk száma elérte az előre beállított maximális értéket.

\subsection{A PPO és a PSGA eredményeinek összehasonlítása}

A PSGA algoritmus alkalmas a munkák és müszakok több ezer különböző kombinációjának szimulációs vizsgálatára. Ez alapján lehetséges a PPO heurisztikus algoritmusunk hatékonyságának vizsgálata. Példaként 30000 különböző PSGA által generált termelési terv szimulációs vizsgálatának eredményeit a 4. ábra mutatja be.

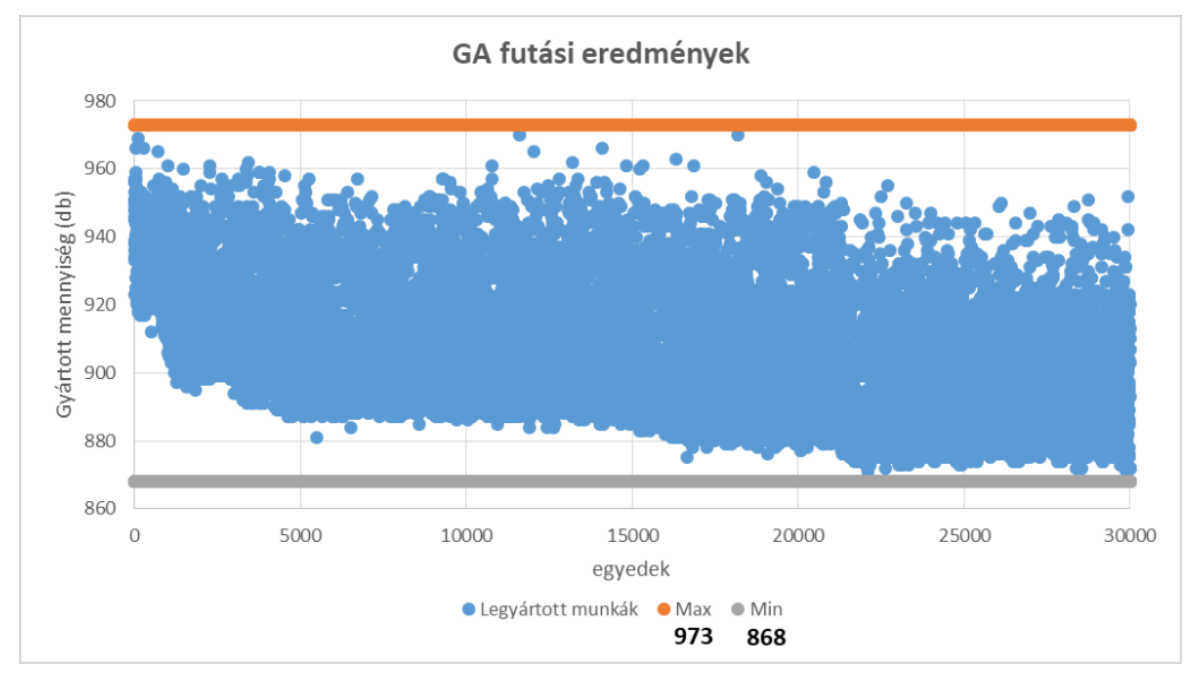

4. ábra. PSGA futási eredmények

A PSGA optimalizálás során a legyártott munkadarabok száma 868 és 973 között ingadozott. A több ezer szimulációs vizsgálat és több órás futás idő ellenére sem találta meg a munkák és müszakok azon összerendelését, amelyet a PPO algoritmussal meghatároztunk. A PSGA hátránya az újabb populációk generálásakor, hogy csak és kizárólag a genetikus operátorok beállításait veszi figyelembe a munkák müszakokhoz való hozzárendelésének egyéb szempontjait nem, szemben az általunk bemutatott célirányosan megtervezett heurisztikus kereső algoritmussal.

\section{4. Összefoglalás}

Cikkünkben bemutattunk egy rugalmas gyártórendszert, amelyben a humán erőforrás kulcsszerepet játszik. Ennek vizsgálatára létrehoztunk egy digitális szimulációs modellt. Kidolgoztunk egy új heurisztikus algoritmust a müszakonkénti termelési terv optimalizálására.

A saját módszerünket összehasonlítottuk a Plant Simulation szoftver genetikus algoritmusával. Az elvégzett tesztek igazolták, hogy a célirányosan felépített kereső algoritmusunk hatékonyabban oldja meg a termeléstervezési feladatot, mint a genetikus algoritmus. 
A vizsgálatunk elvégzése szükségessé tette a termeléstervezési feladat transzformációját adott számú elem permutációjának optimalizálására. Kidolgoztunk egy modell-transzformációs sémát, melynek segítségével többféle optimalizálási feladat visszavezethető permutációs optimalizálási feladatra. Ennek felhasználásával az általános célú meta-heurisztikus kereső algoritmusok egyszerűen változtatás nélkül felhasználhatók ilyen feladatok megoldására.

Egy kvázi-optimális müszakszintủ termelési terv elkészítése nagymértékben növeli a termelési rendszer hatékonyságát. Az elért eredmények alátámasztják, hogy a termeléstervezési és ütemezési modellekben integráltan meg kell jelennie az emberi faktornak annak érdekében, hogy a rendszer hatékonyságnövelésére tett változtatások a kívánt hatást érjék el.

\section{Köszönetnyilvánítás}

A cikkben ismertetett kutató munka az EFOP-3.6.1-16-2016-00011 jelü „Fiatalodó és Megújuló Egyetem - Innovatív Tudásváros - a Miskolci Egyetem intelligens szakosodást szolgáló intézményi fejlesztése" projekt részeként - a Széchenyi 2020 keretében - az Európai Unió támogatásával, az Európai Szociális Alap társfinanszírozásával valósul meg.

\section{Irodalom}

[1] Kagermann, H., Helbig, J., Hellinger, A., Wahlster, W.: Recommendations for implementing the strategic initiative INDUSTRIE 4.0. Forschungsunion, Frankfurt/Main, 2013.

[2] ElMaraghy, H., ElMaraghy, W.: Smart Adaptable Assembly Systems, Procedia CIRP 2016, 44:4-13. https://doi.org/10.1016/j.procir.2016.04.107

[3] Faccio, M.: The impact of production mix variations and models varieties on the parts-feeding policy selection in a JIT assembly system, International Journal of Advanced Manufacturing Technology 2014, 72(1-4):543-560. https://doi.org/10.1007/s00170-014-5675-0

[4] Ferjani, A., Ammar, A., Pierreval, H., Elkosantini,S.: A simulation-optimization based heuristic for the online assignment of multi-skilled workers subjected to fatiguein manufacturing systems, Computers\&IndustrialEngineering 2017, 112:663-674.

https://doi.org/10.1016/j.cie.2017.02.008

[5] Brucker, P.: Scheduling Algorithms, Springer, 2007, ISBN 978-3-540-69515-8.

[6] Garey, M., R., Johnson, D., S., Sethi, R.: The Complexity of Flowshop and Jobshop Scheduling, Mathematics of Operations Research 1976, 1(2):117-129.

https://doi.org/10.1287/moor.1.2.117

[7] Kulcsár, Gy., Erdélyi, F.: A New Approach to Solve Multi-Objective Scheduling and Rescheduling Tasks, International Journal of Computational Intelligence Research 2007, 3(4):343-351. https://doi.org/10.5019/j.ijcir.2007.115

[8] Kulcsár, Gy.: Ütemezési modell és heurisztikus módszerek az igény szerinti tömeg-gyártás finomprogramozásának támogatására, Doktori $(\mathrm{PhD})$ értekezés, Miskolci Egyetem, MiskolcEgyetemváros, 2007.

[9] Kulcsárné, F. M.: Kiterjesztett modellek és módszerek erőforrás-korlátos termelésütemezési feladatok megoldására, Doktori (PhD) értekezés, Miskolci Egyetem, Miskolc-Egyetemváros, 2017.

[10] Kulcsár, Gy., Kulcsárné, F. M.: Kiterjesztett termelésprogramozási modell eröforrás-korlátos ütemezési feladatok megoldására, Multidiszciplináris tudományok 2014, 4(1):19-30. 
[11] Botta-Genoulaz, V.: Hybrid flow shop scheduling with precedence constraints and time lags to minimize maximum lateness, International Journal of Production Economics 2000, 64:101-111. https://doi.org/10.1016/S0925-5273(99)00048-1

[12] Low, C.: Simulated annealing heuristic for flow shop scheduling problems with unrelated parallel machines, Computers and Operations Research 2005, 32:2013-2025. https://doi.org/10.1016/j.cor.2004.01.003

[13] Demir, Y., İşleyen, S. K.: Evaluation of mathematical models for flexible job-shop scheduling problems, Applied Mathematical Modelling 2013, 37(3):977-988. https://doi.org/10.1016/j.apm.2012.03.020

[14] VDI-Richtlinie 3633 Blatt 1: Simulation von Logistik-, Materialfluss- und Produktionssystemen-Grundlagen, Düsseldorf, VDI-Verlag, 1993.

[15] Thengade, A., Donald, R.: Genetic Algorithm - Survey Paper, International Journal of Computer Applications 2012:25-29. ISSN: 0975 - 8887.

[16] McCall, J.: Genetic algorithms for modelling and optimisation, Journal of Computational and Applied Mathematics 2005, 184:205-222. https://doi.org/10.1016/j.cam.2004.07.034

[17] Tóth, N., Kulcsár, Gy.: Rugalmas gyártórendszer hatékonyságának növelése dolgozói képességek szimulációjára alapozott termeléstervezési módszerrel, Multidiszciplináris tudományok 2020, 10(3):130-142. https://doi.org/10.35925/j.multi.2020.3.17 